\title{
Correction: UBE2L6/UBCH8 and ISG15 attenuate autophagy in esophageal cancer cells
}

\section{Chloe M. Falvey ${ }^{1}$, Tracey R. O'Donovan ${ }^{1}$, Shereen El-Mashed ${ }^{3}$, Michelle J. Nyhan ${ }^{1}$,} Seamus O'Reilly², Sharon L. McKenna ${ }^{1}$

${ }^{1}$ Cork Cancer Research Centre, University College Cork, Cork, Ireland

${ }^{2}$ Department of Oncology, Cork University Hospital, Cork, Ireland

${ }^{3}$ Lecturer in Histopathology, National liver institute, Menoufia University, Al Minufya, Egypt

Published: January 14, 2020

Copyright: Falvey et al. This is an open-access article distributed under the terms of the Creative Commons Attribution License 3.0 (CC BY 3.0), which permits unrestricted use, distribution, and reproduction in any medium, provided the original author and source are credited.

This article has been corrected: The affiliation of the $3 \mathrm{rd}$ author has been updated. The correct affiliation information is given below:

${ }^{3}$ Lecturer in Histopathology, National liver institute, Menoufia University, Al Minufya, Egypt

Original article: Oncotarget. 2017; 8:23479-23491. https://doi.org/10.18632/oncotarget.15182 